\title{
Further Clinical Evidence for the Existence of Neurotoxicity in a Population of the European Adder (Vipera berus berus) in Eastern Hungary: Second Authenticated Case
}

\author{
Tamás Malina, MSc; Gergely Babocsay, PhD; László Krecsák, MSc; Csaba Erdész, MD \\ From the Medical Department, Lilly Hungary Ltd, Budapest, Hungary (Mr Malina); the Department of Pharmacognosy, Faculty of Science and \\ Technology, University of Debrecen, Debrecen, Hungary (Mr Malina); the Department of Zoology, Mátra Museum of the Hungarian Natural \\ History Museum, Gyöngyös, Hungary (Dr Babocsay); the Department of Systematic Zoology and Ecology, Eötvös Loránd University, Budapest, \\ Hungary (Mr Krecsák); and the Paediatric Ward, Szatmár-Bereg Hospital, Fehérgyarmat, Hungary (Dr Erdész).
}

\begin{abstract}
We report a recent case of common adder (Vipera berus) envenoming causing paralytic signs and symptoms. A 12-year-old girl was bitten by the nominate subspecies of the common adder ( $V$. berus berus) in eastern Hungary on May 2, 2012, $22 \mathrm{~km}$ away from where the first neurotoxic V. berus berus envenoming was reported in 2008. The patient developed unambiguous cranial nerve disturbances, manifested in bilateral impairment characterized by oculomotor paralysis with partial ptosis, gaze paresis, and diplopia. Drowsiness and photophobia were her additional symptoms; both occurred only during the first day of envenoming. Until now among viper envenomings in Europe, photophobia has only been documented by victims of Vipera aspis. Supportive and symptomatic treatments were administered during 3 days of hospitalization. Although case reports of $V$. berus berus envenomings are often published, clinical experience with neurotoxicity by this subspecies still remains rare. Populationbased and geographic variation of venom composition in $V$. berus berus seems to include neurotoxic envenomings in certain populations. This second authenticated case provides new clinical evidence for the existence of a possible neurotoxic $V$. berus berus population in a restricted geographical area in eastern Hungary.
\end{abstract}

Key words: neurotoxicity, phospholipase $\mathrm{A}_{2}$, photophobia, ptosis, regional venom variability

\section{Introduction}

Two subspecies of the common adder (Vipera berus) occur in Hungary: the nominate subspecies ( $V$. berus berus) in the northeastern mountainous area and the eastern lowland corner of Hungary, and the Balkan subspecies, $V$. berus bosniensis, which reaches its northernmost distribution in the lowlands of southwestern Hungary. ${ }^{1-3}$

The hill country populations of northeastern Hungary are isolated from the lowland adder populations of eastern Hungary. Based on their mitochondrial DNA, these 2 populations belong to 2 different evolutionary

Corresponding author: Tamás Malina, MSc, Medical Department, Lilly Hungary Ltd, Madách Imre utca 13-14, H-1075 Budapest, Hungary (e-mail: malina_tamas@network.lilly.com). clades. $^{4}$ Although they differ slightly also in morphology 3,5 and habitat preferences, 5,6 they are both recognized as $V$. berus berus. . $^{1,5,6}$

Variation in snake venom composition is notably influenced by adaptation to available prey species, ${ }^{7-10}$ and can lead to regionally distinct clinical patterns observed in envenomed patients. ${ }^{7,11-14}$ This venom composition diversity-also occurring within speciescan lead to regionally distinct clinical patterns on envenomed patients. ${ }^{7,14}$ Intraspecific venom variations have been shown also in some European viperids, eg, in the long-nosed viper (Vipera ammodytes) in Croatia ${ }^{15}$ and the asp vipers (Vipera aspis) in France. ${ }^{16}$

The venom of the European viperids has an arsenal of a complex mixture of enzymes. Of the phospholipases $\mathrm{A}_{2}$ $\left(\mathrm{PLA}_{2}\right)$, the post- and presynaptically acting neurotoxins 
(eg, different isoforms of ammodytoxin and vaspin) are the most significant, which can cause peripheral neurotoxic effects on humans. ${ }^{16,17}$ To date in Europe, neurotoxicity in viper envenomings have been described mainly in $V$ aspis zinnikeri in northern $\operatorname{Spain}^{18}$ and southwestern France, ${ }^{16}$ in $V$ aspis aspis in southeastern France, ${ }^{16}$ in $V$ aspis francisciredi in Italy, ${ }^{19,20}$ and in $V$ ammodytes ammodytes in Croatia. ${ }^{21}$ In 1982, Thouin et $\mathrm{al}^{22}$ mentioned a few negligible neurotoxic cases of $V$ ammodytes ammodytes bites in the former Yugoslavia, but did not indicate the exact locality. The bites of certain $V$. berus populations may also cause peripheral neurotoxic effects in humans. ${ }^{23}$ Since the 1930s, it has been known that the venom of $V$. berus bosniensis is capable of inducing neurological disturbances dominated by cranial nerve dysfunctions. ${ }^{24}$ However, the first authenticated case reports and clinically oriented papers about neurotoxic $V$. berus bosniensis envenomings were published only in the last 2 years. ${ }^{25,26}$ Neurological deficits after envenoming by the nominate subspecies of $V$. berus are rarely reported. A few cases of neurotoxic envenoming by $V$. berus berus have been reported in Germany. In these cases, symptoms included ptosis and dysphagia. $^{27}$ Other, western Transylvanian neurotoxic envenomings were summarized by Malina et al in $2008 .^{28}$

Here, we present a case of envenoming by $V$. berus berus, in which some of the symptoms were unequivocally consistent with neurotoxicity. This incident occurred near $(22 \mathrm{~km})$ the location where the first eastern Hungarian neurotoxic envenoming by $V$. berus berus was documented. ${ }^{29}$

\section{Case Report}

A healthy 12-year-old girl (body weight, $50 \mathrm{~kg}$ ) was bitten by a snake during a school trip in Túristvándi (Szabolcs-Szatmár-Bereg County), eastern Hungary on May 2, 2012 at approximately 4:30 PM. The girl confidently grabbed the snake, as she believed it was only a harmless grass snake (Natrix natrix). The 50- to $60-\mathrm{cm}$ long snake immediately bit her. The culprit specimen had been photographed with a mobile phone by one of her schoolmates (owing to its poor resolution, the photo is omitted, but is on file and available for inspection on request to the senior author). Later, the snake was identified as a melanistic $V$. berus berus specimen by a keeper from the Venomous Snake Department of the Budapest Zoo, and the identification was reconfirmed by a ranger of the Directorate of Hortobágy National Park (Hungary).

Throbbing pain and local swelling developed within minutes after the bite, suggesting that venom had been injected. The girl received first aid (500 mg of CalciumSandoz [calcium] tablet and cold pack) from her teacher and was taken to the local general physician (GP) office. By then she was drowsy and nauseated, but fully conscious. She had no history of snakebite and declared no allergies. The GP requested the transport of the patient to the nearest hospital (Szatmár-Bereg Hospital, Fehérgyarmat). She was transported by ambulance, and admitted to the pediatric ward.

On admission (7:12 PM), the girl's whole left hand was edematous, tense, and painful on palpation. Mild hyperemic discoloration was observed on the dorsum of the hand. There were 2 fang marks approximately 5 to $8 \mathrm{~mm}$ apart on the extensor side of the left index finger, and another puncture mark was visible on the finger's radial aspect. The victim was pale, weak, and prostrated and was unable to stand. She repeatedly retched and, on a few occasions, regurgitated. On arrival her blood pressure, heart rate, and respiration rate were $109 / 70 \mathrm{~mm} \mathrm{Hg}$, 99 beats/min, and 13 breaths/min, respectively. She complained of intensive dizziness and was still drowsy but able to be aroused. The sensorium remained clear, and she was able to give adequate answers when questioned. According to the patient, double vision first developed about 20 to 30 minutes after the bite. During the neurological examination, her pupils were moderately dilated, and mild abnormality of pupillary accommodation was detected. Although she could partially open her eyes on request, palpebral ptosis was obvious. The patient described photosensitivity in the presence of ambient light and experienced eye movement difficulties. Medical examination confirmed a bilateral impairment characterized by oculomotor paralysis with partial bilateral ptosis and gaze paresis but no other cranial nerve or additional neurological deficits were observed. The patient preferred remaining in a lying position because it mitigated the intensity of dizziness occurring when sitting or standing.

Immediate routine laboratory tests did not show abnormalities in blood coagulation, assessed by prothrombin $(73.3 \%$; normal, $70-100 \%)$, international normalized ratio (INR, 1.17; normal, 1.00-1.20), activated prothrombin time (APTI, 23.7 seconds; normal, $<42.0$ seconds), and thrombin time (TT, 18.80 seconds; normal, $<22.0$ seconds). Only slight elevations in blood glucose (6.50 mmol/L; normal, 3.30-6.00 mmol/L) and plasma calcium (2.64 $\mathrm{mmol} / \mathrm{L}$; normal, $2.15-2.60 \mathrm{mmol} / \mathrm{L})$ were observed. Within approximately 4 hours of postbite supportive therapy, 1 vial $(5 \mathrm{~mL})$ of Calcimusc injection (calcium, $100 \mathrm{mg} / \mathrm{mL}$ intramuscularly), isotonic saline (Ringer's lactate solution, $500 \mathrm{~mL} \mathrm{IV}$ ), tetanus prophylaxis, corticosteroid (120 mg of methylprednisolone, IV), and antibiotic therapy (850 $\mathrm{mg}$ of amoxicillin-clavulanic 
acid IV every day) was administered. The latter was maintained longer than 48 hours. Antivenom was not administered because the treating physician considered it unnecessary.

Next morning (May 3, 2012) the retching and regurgitation ceased. Laboratory results showed slight deviations from normal: C-reactive protein, $7.2 \mathrm{mg} / \mathrm{L}$ (reference range, $<5 \mathrm{mg} / \mathrm{L}$ ); white blood cells, 17.96 $10^{3} / \mathrm{L}$ (reference range, 4.5-13.0 $10^{3} / \mathrm{L}$ ); neutrophils, $87 \%$ (reference range, 40-74\%); lymphocytes, $7 \%$ (reference range, 19-41\%); and density of urine, 1015.000 (reference range, 1.005-1.020). Some blood coagulation parameters showed an increasing trend as compared with those on the admission day (ie, APTI, 25.7 seconds [normal, $<42.0$ seconds], TT, 20.90 seconds [normal, $<22.0$ seconds]), but remained within the normal range. The patient could open her eyes easier, but bilateral ptosis was still present, and the hand edema started to decease.

On May 4, 2012, the patient showed no systemic symptoms, and the hand edema, as well as hyperemia, was significantly reduced. The cranial nerve palsies resolved, and there were no further peripheral neurotoxic signs and symptoms. She remained stable and was discharged the next day (May 5, 2012) after an uneventful recovery.

\section{Discussion}

The composition of snake venom is highly plastic and is influenced by several genetic and non-genetic factors. ${ }^{12,29}$ Knowledge about geographic venom variations is of key importance to clinical toxinologists when selecting the appropriate therapy. ${ }^{7,10,12}$ In Europe, bites of $V$ aspis show fascinating variation in the clinical pictures of envenomed patients. ${ }^{16,18-20,30,31}$ Similar diversity of symptoms was reported in studies on the Russell's viper (Daboia russelii) envenomings in Asia. ${ }^{13,14,32}$ These clinical reports demonstrate the great medical relevance of the regional venom variability of a given snake species. ${ }^{7}$

A large number of reports have been issued about the clinical aspects of $V$. berus envenoming since Reid's pioneering work. ${ }^{33}$ Neurotoxic envenomings from northwestern, northern, and central Europe were seldom recorded. ${ }^{27,28,34,35}$ Individual case reports on neurotoxic signs and symptoms indicate that isolated neurotoxic $V$. berus berus populations might exist in Europe, mostly within the Carpathian basin ${ }^{28,36}$ and in certain parts of Germany. ${ }^{27,34,35}$

Our case presents further unequivocal evidence for the existence of a neurotoxic population of $V$. berus berus in eastern Hungary. In our patient, oculomotor palsy manifested as partial bilateral ptosis, gaze palsies, and consequent diplopia. The patient tried to compensate her gaze palsy by turning her head instead of moving her eyes. These neurological signs and symptoms suggest that cranial nerves III, IV, and VI were affected by the paresis. Her ptosis persisted through the second day. Ptosis is one of the early signs of neuromuscular paralysis in snakebites, although it is easily missed in neurotoxic Vipera spp envenomings. Patients often develop ptosis lasting less than a day as was reported in $V$. berus bosniensis ${ }^{25,26}$ or $V$ aspis francisciredi bites. ${ }^{19}$ Gaze paresis, dysphagia, and dysarthria are the most documented and frequent neurological signs of neurotoxic viper envenomings in Europe. ${ }^{16,18-}$ 21,25,26,28,30,31,36 Photophobia was documented only in $V$ aspis bites from a limited area in southeastern France, where neurotoxic envenomings are frequent. ${ }^{30}$ In our case, this particular clinical feature was assessed subjectively while relying on the description of the patient. According to her, she experienced it only on the first day after the incident. We deem it was related to neurotoxicity. The origin of drowsiness in the envenomings by European viperids is debated. It is considered to be either caused by venom-induced endorphin release, ${ }^{37}$ vasovagal responses, and central nervous system depression ${ }^{38}$ or regarded as a neurotoxic symptom, occasionally reported in $V$ aspis aspis, $V$ aspis zinnikeri, ${ }^{30,31}$ and $V$ aspis francisciredi envenomings. ${ }^{19}$ Drowsiness also developed in a neurotoxic envenoming by $V$. berus in southeastern Romania in $2012 .{ }^{36}$ In this case the taxon was erroneously recorded as $V$. berus bosniensis by the authors because only $V$. berus berus occurs in Romania. ${ }^{39,40}$ The weakness and prostration of the girl was most noticeable during the first day of hospitalization. Likely it was a consequence of dehydration owing to repetitive vomiting. Her inability to stand was most probably caused by her weakness, intensive dizziness, and the slight disturbances of fluid retention.

Variation in snake venom composition and its pharmacology have been studied in several species. A number of observations reveal that the effects of the bites inflicted by snakes of the same population can vary. ${ }^{14,16,41,42}$ Intrapopulation venom variability may derive from several different causes: prey specificity, ontogenetic variation, and other ecological pressures. ${ }^{43-45}$ In southeastern France, some specimens of $V$ aspis may produce more varied clinical manifestations-mainly in neurological disturbances - on envenomed humans than others as a result of their more complex venom composition, especially because of their higher $\mathrm{PLA}_{2}$ arsenal variability. ${ }^{16}$ Intrapopulation venom variability has already been known in the eastern Hungarian adders. 
This is caused by a geographical variation in the biochemical composition (eg, qualitative and quantitative variability of $\mathrm{PLA}_{2}$ content [Malina and Vasas, unpublished data]) and the neuromuscular activity of the venom (Malina et al, unpublished data). However, neurotoxic manifestations in envenomings occur only occasionally within this region. ${ }^{46}$

Currently there is no officially recommended or widely accepted protocol for snakebite treatment in Hungary. Most Hungarian physicians have limited experience with snakebite therapy owing to the rarity of envenomings by the native species in comparison to other European countries. ${ }^{47,48}$ Consequently, glucocorticoid, antibiotic, and antitetanus therapies are still applied as supportive treatment in cases of snakebite. Although in Hungary glucocorticoids and calcium are administered in most cases of adder bites ${ }^{49,50}$ and bee and wasp stings, these are generally contraindicated practices. Also, the provision of oral calcium is not evidence-based, but Hungarian victims of $V$. berus sometimes apply it as a first aid. ${ }^{28,49}$ Similarly, although cryotherapy is widely contraindicated in snakebites ${ }^{51}$ and routine antibiotic prophylaxis has no general supporting evidence, ${ }^{52}$ in Hungary both were, ${ }^{49}$ and still are, administered ${ }^{50}$ in case of adder bites. Other contraindicated first aid methods such as washing of the bite site with potassium permanganate $(1 \%)$ or hydrogen peroxide (3\%) solution is still recommended for $V$. berus envenomings, as the Hungarian medical literature of the last decades shows. ${ }^{50,53}$

Unfortunately, a false, underestimating conception on the possible consequences of $V$. berus envenoming persists in Hungary. It is often believed that the venom of this taxon is weak and poses little risk for human health. ${ }^{48}$ Hungarian physicians often opt for antivenom therapy inconsistently without well-founded evidence supporting their decision. ${ }^{47}$ Virágh and Tass $^{53}$ have also highlighted that antivenom is often administered unnecessarily in viper bites, when it is not indicated (eg, dry bites or when only mild local symptoms develop), while it is often not administered in clinically indicated cases. Two antivenoms are available against the venom of $V$. berus in Hungary: the Ipser Europe and the European Viper Venom Antiserum. ${ }^{48}$ The latter was on storage in the hospital where our patient was treated. The treating physician hesitated to administer the antivenom; finally the patient's symptoms ameliorated and did not necessitate the use of it. In our opinion, the early antivenom administration could have lessened the degree of neurotoxic manifestations.

The culprit adder of this incident belongs to an eastern Hungarian $V$. berus berus population different from the one in which the first neurotoxic envenoming was reported in $2008 .^{28}$ This recent envenoming occurred a mere $22 \mathrm{~km}$ from the previous location. The 2 adder populations are isolated from each other by the River Tisza. Such geographical isolation may lead to venom variability $^{7,11,14,32,41}$; therefore, physicians need to pay more attention to uncommon features of envenoming that may be attributed to geographic variability.

Although several reviews and case reports on $V$. berus bites are published, clinical experience with neurotoxic envenomings by the nominate subspecies ( $V$. berus berus) remains limited. This recent case supports our contention that envenomings by certain populations of this taxon may cause paralytic features. The patient described here presented with moderate local symptoms followed by neurological disturbances primarily manifested as dysfunction of certain cranial nerves. This second authenticated case provides further clinical evidence for the existence of a neurotoxic $V$. berus berus populations in a restricted geographical area in eastern Hungary.

\section{Acknowledgments}

We thank Dr Gábor Kovács (Medical Director of Szatmár-Bereg Hospital, Fehérgyarmat, eastern Hungary) for the permission to use the medical case records and the Directorate of Hortobágy National Park for the information on the local adder populations.

\section{References}

1. Dely OG, Marián M. Contributions à l'étude de la répartition de la Vipère commune (Vipera berus LINNÉ) en Hongrie [in French]. Vert Hung. 1960;2:175-188.

2. Dely OG. Reptiles-Reptilia [in Hungarian]. Fauna of Hungary (Fauna Hungariae). 1978;20:1-120.

3. Korsós Z, Krecsák L. Taxonomy and ecology of the Hungarian populations of the common adder (Vipera berus). 5th World Congress of Herpetology, 2005 Jun 19-24. South Africa: Stellenbosch; 2005:136-137.

4. Kalyabina-Hauf S, Schweiger S, Joger U, Mayer W, Orlov N, Wink M. Phylogeny and systematics of adders (Vipera berus complex). Mertensiella. 2004;15:7-16.

5. Marián M. Data to the herpetofauna of the Upper Tisza River valley. In: Bálint A, ed. Móra Ferenc Múzeum Évkönyve 1958-1959 [in Hungarian]. Szeged: Szegedi Nyomda Vállalat; 1960:259-275.

6. Korsós Z. History of the Hungarian herpetofauna after the glacial. In: Forró L, ed. Evolution of the Hungarian Fauna of the Carpathian-Basin [in Hungarian]. Budapest: Magyar Természettudományi Múzeum; 2007:283-296.

7. Chippaux J-P, Williams V, White J. Snake venom variability: methods of study, results and interpretation. Toxicon. 1991;29:1279-1303.

8. Daltry JC, Wüster W, Thorpe RS. The role of ecology in determining venom variation in the Malayan pitviper, 
Calloselasma rhodostoma. In: Thrope RS, Wüster W, Malhotra A, eds. Venomous Snakes: Ecology, Evolution and Snakebite. Oxford: Symposia of the Zoological Society of London; 1997:155-171.

9. Barlow A, Pook CE, Harrison RA, Wüster W. Coevolution of diet and prey-specific venom activity supports the role of selection in snake venom evolution. Proc $R$ Soc $B$. 2009;276:(2443-249).

10. Babocsay G. Molecular versus morphological methods in taxonomy; a toxic case: the Echis coloratus complex [in Hungarian with English abstract]. Állattani Közlemények. 2010;95:179-190.

11. Chippaux J-P. The composition of the venom - the venom apparatus: Part II. Venoms. In: Chippaux J-P, ed. Snake Venoms and Envenomations. Malabar, FL: Krieger Publishing; 2006:47-73.

12. Mackessy SP. The field of reptile toxinology-snakes, lizards, and their venoms. In: Mackessy SP, ed. Handbook of Venoms and Toxins of Reptiles. London: CRC Press, Taylor \& Francis Group; 2009:3-23.

13. Warrell DA. Geographical and intraspecies variations in the clinical manifestations of envenoming by snakes. In: Thorpe RS, Wüster W, Malhotra A, eds. Venomous Snakes: Ecology, Evolution and Snakebite. Oxford: Clarendon Press; 1997:189-203.

14. Belt PJ, Malhotra A, Thorpe RS, Warrell DA, Wüster W. Russell's viper in Indonesia: snakebite and systematics. In: Thrope RS, Wüster W, Malhotra A, eds. Venomous Snakes: Ecology, Evolution and Snakebite. Oxford: Clarendon Press; 1997:219-234.

15. Balija ML, Vrdoljak A, Habjanec L, et al. The variability of Vipera ammodytes ammodytes venoms from Croatiabiochemical properties and biological activity. Comp Biochem Physiol C. 2005;140:257-263.

16. Ferquel E, de Haro L, Jan V, et al. Reappraisal of Vipera aspis venom neurotoxicity. PLoS One. 2007;2: e1194.

17. Jan VM, Guillemin I, Robbe-Vincent A, Choumet V. Phospholipase $\mathrm{A}_{2}$ diversity and polymorphism in European viper venoms: paradoxical molecular evolution in Viperinae. Toxicon. 2007;50:1140-1161.

18. González D. Clinical aspects of bites by viper in Spain. Toxicon. 1982;20:349-353.

19. Beer E, Putorti F. Dysphonia an uncommon symptom of systemic neurotoxic envenomation by Vipera aspis bite. Report of two cases. Toxicon. 1998;36:697-701.

20. Lonati D, Rossetto O, Cintra-Francischinelli M, et al. Clinical and experimental evidence of Italian viper venom neurotoxicity. Clin Toxicol. 2009;47:485-486.

21. Lukšić B, Bradarić N, Prgomet S. Venomous snakebites in southern Croatia. Coll Antropol. 2006;30:191197.

22. Thouin Jr LG, Ritonja A, Gubenšek F, Russell FE. Neuromuscular and lethal effects of phospholipase A from Vipera ammodytes venom. Toxcion. 1982;20:1051-1058.

23. Warrell DA. Snakebite envenoming: clinical and therapeutic aspects. 17th Congress of the European Section of the International Society on Toxinology. 2011 Sep 11-15. Valencia, Spain: 2011:26.

24. Schöttler WHA. About the Vipera latasti and Vipera lebetina [in German]. Z Hyg Infektionskr. 1938;120: 408-434.

25. Westerström A, Petrov B, Tzankov N. Envenoming following bites by the Balkan adder Vipera berus bosniensis-first documented case series from Bulgaria. Toxicon. 2010;56:1510-1515.

26. Malina T, Krecsák L, Jelić D, et al. First clinical experiences about the neurotoxic envenomings inflicted by lowland populations of the Balkan adder, Vipera berus bosniensis. Neurotoxicology. 2011;32:68-74.

27. Francke E. Clinical manifestations and therapy of the envenoming by the Adder [in German]. Fühner-Wielands Sammlung von Vergiftungsunfällen. 1937;36:1-12.

28. Malina T, Krecsák L, Warrell DA. Neurotoxicity and hypertension following European adder (Vipera berus berus) bites in Hungary: case report and review. QJM. 2008;101:801-806.

29. Starkov VG, Osipov AV, Utkin YN. Toxicity of venoms from vipers of Pelias group to crickets Gryllus assimilis and its relation to snake entomophagy. Toxicon. 2007; 49:995-1001.

30. de Haro L, Robbe-Vincent A, Saliou B, Valli M, Bon C, Choumet V. Unusual neurotoxic envenomations by Vipera aspis aspis snakes in France. Hum Exp Toxicol. 2002;21: 137-145.

31. de Haro L, Glaizal M, Tichadou L, Blanc-Brisset I, HayekLanthois M. Asp viper (Vipera aspis) envenomation: experience of the Marseille Poison Centre from 1996 to 2008. Toxins (Basel). 2009;1:100-112.

32. Mukherjee AK, Ghosal SK, Maity CR. Some biochemical properties of Russell's viper (Daboia russelli) venom from Eastern India: correlation with clinic-pathological manifestation in Russell's viper bite. Toxicon. 2003;38:163175.

33. Reid HA. Adder bites in Britain. Br Med J. 1976;2:153156.

34. Otto R. Investigation on the venoms of the European Viperids [in German]. Z Hyg Infektionskr. 1929;110:82-92.

35. Reuss T. [No title] (under Vereinsnberichte - "Lacerta," Gesellschaft für Terrarienkunde. Berlin) [in German]. Nachrichtenblatt für Aquarien- und Terrarien-Vereine. 1933;8:98-99.

36. Gafencu M, Doros G, Badeti R, Vasilie D. Envenoming by Vipera berus: a case report of neurotoxicity. Clin Toxicol. [EAPCCT Abstracts] 2012;4:286.

37. Warrell DA. Clinical features of envenoming from snake bites. In: Bon C, Goyffon M, eds. Envenoming and Their Treatments. Lyon, France: Fondation Marcel Merieux; 1996:63-76.

38. Persson H. Clinical toxicology of snakebite in Europe. In: Meier J, White J, eds. Handbook of Clinical Toxicology of Animal Venoms and Poisons. New York, NY: CRC Press, Taylor \& Francis Group; 1995:413432. 
39. Ursenbacher S, Carlsson M, Helfer V, Tegelström $H$, Fumagalli L. Phylogeography and Pleistocene refugia of the adder (Vipera berus) as inferred from mitochondrial DNA sequence data. Mol Ecol. 2006;15:3425-3437.

40. Zinenko O, Ţurcanu V, Strugariu A. Distribution and morphological variation of Vipera berus nikolskii Vedmederja, Grubant et Rudaeva, 1986 in Western Ukraine, The Republic of Moldova and Romania. Amphibia-Reptilia. 2010;31:51-67.

41. Alape-Girón A, Sanz L, Escolano J, et al. Snake venomics of the Lancehead pitviper Bothrops asper: geographic, individual, and ontogenetic variations. J Proteome Res. 2008;7:3556-3571.

42. Öhler M, Georgieva D, Seifert J, et al. The venomics of Bothrops alternatus is a pool of acidic proteins with predominant hemorrhagic and coagulopathic activities. $J$ Proteome Res. 2010;9:2422-2437.

43. Sasa M. Diet and snake venom evolution: can local selection alone explain intraspecific venom variation? Toxicon. 1999;37:249-252.

44. Wüster W, Daltry JC, Thorpe RS. Can diet explain intraspecific venom variation? Reply to Sasa. Toxicon. 1999;37:253-258.

45. Willimas V, White J, Schwaner TD, Sparrow A. Variation in venom proteins from isolated populations of tiger snakes (Notechis ater niger, N. scutatus) in South Australia. Toxicon. 1988;26:1067-1075.
46. Malina T. Clinical picture of the envenomings by different populations of the common adder (Vipera berus) in Hungary. 17th Congress of the European Section of the International Society on Toxicology. 2011 Sep 11-15. Valencia, Spain: 2011:32.

47. Malina T, Krecsák L, Korsós Z, Takács Z. Snakebites in Hungary-epidemiological and clinical aspects over the past 36 years. Toxicon. 2008;51:943-951.

48. Malina T, Babocsay G, Krecsák L, Schuller P, Zacher G, Vasas G. An overview on envenomings inflicted by the common adder (Vipera berus) and their treatment in Hungary. Fact and beliefs-part I [in Hungarian with English abstract]. Orv Hetilap. 2012;28:1092-1105.

49. Virágh I, Tass G. Vipers in the Zemplén mountains. Retrospective survey on intoxications [in Hungarian with English abstract]. Borsodi Orv Szle. 1986;2: 209-222.

50. Sziray Á, Károlyi Z. Management of the common European viper's bite [in Hungarian with English abstract]. Orv Hetilap. 2011;41:1661-1665.

51. Warrell DA. Snake bite and snake venoms [editorial]. QJM. 1993;86:351-353.

52. Warrell DA. Treatment of bites by adders and exotic venomous snakes. BMJ. 2005;331:1244-1247.

53. Virágh I, Tass G. Adders in the Zemplén Mountains [in Hungarian]. Kórház. 2002;10:33-41. 